\title{
ALPHA EMITTERS RADIOACTIVITY CONCENTRATIONS IN SOME COSMETICS USED IN IRAQ USING LR-115 DETECTOR
}

\author{
Malik H. Kheder \\ Department of Physics ${ }^{1}$ \\ malik.19732013@yahoo.com \\ Hanaa N. Azeez \\ Department of Physics ${ }^{1}$ \\ akrawyhana@gmail.com \\ Firas M. Al-Jomaily \\ Department of Physics \\ Science College \\ Mosul University \\ AL-majmoaa Street, Mosul, Iraq, 41001 \\ aljomaily16@gmail.com \\ ${ }^{1}$ Education College \\ University of AL-Hamdaniya \\ Erbil road, Al- Hamdaniya District, Nineveh, Iraq, 41006
}

\begin{abstract}
Cosmetics play an important role of human external appearance, its products used to alter or enhance the facial appearance or the body and skincare, currently worldwide consumed with frequently use increasing the human body exposure to the various chemical elements including radioactive substances. This research aimed to measure the concentrations of alpha emitters, and the annual effective dose AED resulting from radon intake. LR-115 track detector used to measure radon, and radium concentrations in 20 cosmetics samples selected from markets. In this work the concentrations of radon in the samples found to vary from 9.876 to $30.97 \mathrm{~Bq} / \mathrm{m}^{3}$ with $22.11 \mathrm{~Bq} / \mathrm{m}^{3}$ a mean value, this mean value is a very small than $100 \mathrm{~Bq} / \mathrm{m}^{3}$ the reference level limits of the World Health Organization (WHO). The annual radon effective dose varied between $0.249-0.781 \mathrm{mSv} / \mathrm{y}$ which is within the range of $0.2-10 \mathrm{mSv} / \mathrm{y}$ (UNSCEAR). Radium contents vary between $0.041-0.249 \mathrm{~Bq} / \mathrm{Kg}$ with $0.115 \mathrm{~Bq} / \mathrm{Kg}$ as a mean value. This work identified law measured concentrations of radionuclide present in cosmetics showed its safe for use.
\end{abstract}

Keywords: radium concentration, effective radon dose, LR-115 detector, cosmetics, radon concentration.

DOI: $10.21303 / 2461-4262.2020 .001171$

\section{Introduction}

Cosmetics are important elements in hygiene and health, they are the substances with a slight effect on human's body, which applied to the body by rubbing, spraying or other uses, are aimed at cleaning and beautifying, increasing attractiveness, and keep the hair or skin in good condition or changing the appearance. Cosmetics categorized into makeup cosmetics, special purpose cosmetics, hair care products, skincare cosmetics, and perfume, including lipsticks, foundation creams, skin milk, face cream, eye makeup, cleaning cream, skin wash, hair dye, soap, shampoo hair treatment, and sunscreen [1]. The cosmetic word is derived from "kosm tikos" the Greek word, which means haves the power, arrangement and decorating skill. The prehistoric man 3000BC used colors for decoration to attract the animals it wanted to hunt, and the man escaped an attack from the enemy by coloring its skin and decorating its body for protection to stir fear in the enemy (be it a man or an animal) [2]. Since ancient times, the man was aiming to persuade others of their appearance; at that time there were no creams for fairness or any cosmetic surgery to alter the appearance and maintenance of the skin due to excessive exposure to heat that would dry during the summer and cause wrinkles, freckles, blemishes, pigmentation, and 
sunburn. Harsh winter causes damage to the skin in the form of cracks, wounds, smoothing and infection [3]. Cosmetic first expressed Roman slaves whose job was to prepare perfume baths for women and men to take in. In Egypt, before 10,000 BC, people used oils and scented ointments to mask their body odor and to cleanse and soften the skin. The skin, hair, and body were colored with paints and dyes [4]. Women and men in the Ancient Sumerian 5,000 years ago were the first possibly to invent and wear lipstick. They crushed gemstones and used it to their faces decorate, on the lips and around the eyes [5]. The traditional cosmetics Henna and kohl are used in North Africa and the Middle East. Henna was used since ancient times to skin dye, hair, and nails [6], they used henna in dye Their nails, red lips, and cheeks, as they used kohl to line their eyebrows and eyes. Kohl is a black powder composed from crushed antimony, lead, burning almonds, ashes, copper oxide, ocher, malachite, and blue copper ore or green copper. It is used to paint the lower and upper eyelids in a line stretched on both face sides for the effect of almonds. In addition to reducing the glare of the sun, kohl was believed that it can strengthen weak eyesight and reduce infections of the eye [7]. When radium was discovered, scientists dreamed that they had discovered the "secret of beauty". Because radium radiation is vital, it stimulates all living tissues. This energy turned into auxiliary factors for beauty [8]. Radium containing cosmetics was found in products of London-based Radior company in 1917 when it began marketing the cosmetics, including a compact powder, night cream, vanishing cream, rouge, hair tonic, skin soap, talcum powder, and face powder. An owing youth fountain and beauty have been found in the radium ray energy. The continuous energy current owns into the skin and before wrinkles disappeared, the nerves become energized and strong, and the tired muscles become braced up [9]. The radium use would be impossible because of its harmful effects on the body and the skin. Radon, which is the gas released from radium, and into the cream impregnated, is the constituent gives values of the cream. Since radon eliminated completely within six hours from the skin, therefore no ill effects danger through its accumulation, understand this form of the approved treatment of the scientific and medical authorities. The rising of the cosmetic products, use with larger compounds formulas exposure for a large frequency and time, these products side effects become more frequent in the population. Over the world, people use cosmetics in large amount in pursuit of youth everlasting, ignoring health risks [10]. Human exposure to radioactive elements faces health risks that affect their lives and reflect on future generations. The human body damage from the radioactive elements depends on, radiation type, the time the body is exposed to, and the nature of the radioactive material [11]. Radioactive substances are absorbed and introduced into basic biochemical processes and access to a circulation of the blood and body fluids, are distributed to all body tissues according to the element properties [12]. Radon, radium, and uranium, these fatal elements if consumed, they lead to malfunction damage in the bones, kidneys, the radon is an important element that can cause lung cancer, So their quantity must be under control [13].

This research aimed to measure the alpha particles emitters radon and radium concentrations, and the annual effective dose AED resulting from radon intake in cosmetics samples selected from Iraqi markets, because the cosmetics are important in human external appearance, and its currently worldwide consumed with high frequently increasing the human body exposure to the various chemical elements including radioactive substances, which causing health risks, so measuring their concentration to ensure they are in permissible levels. The sealed cans with the LR-115 detector technique used in radioactive measurements of cosmetics samples.

\section{Material and methods}

Twenty samples were collected from most used cosmetics, filled inside a cylindrical plastic container (sealed-can with diameter $4 \mathrm{~cm}$, length of $10.5 \mathrm{~cm}$ ) LR-115 track detector facing, $7.5 \mathrm{~cm}$ is the distance from the detector to surface of the sample, $3 \mathrm{~cm}$ is the thickness of the sample (Fig. 1). The detectors after 60 days etched by $\mathrm{NaOH}$ at $2.5 \mathrm{~N}$ normality and heat $60{ }^{\circ} \mathrm{C}$ for 2 hours in a water bath. The detectors dried after washing in water, by a microscope at 400x a magnification tracks counted. 


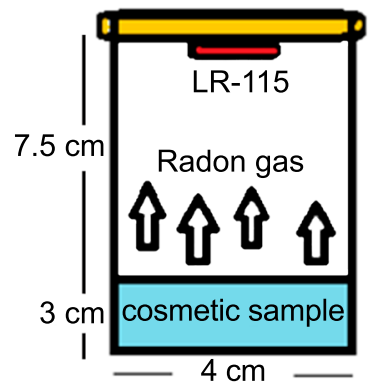

Fig. 1. The diagram of a sealed-can for cosmetic samples

The radon concentration determined from the density of tracks on a detector $\rho\left[\operatorname{track} / \mathrm{m}^{2}\right]$. The track density equal to the total number of tracks per the area of the field of view of the detector by microscope, is a measurable quantity related to radon concentration $C_{R n}\left[\mathrm{~Bq} / \mathrm{m}^{3}\right]$ through the detector sensitivity $K[\mathrm{~m}]$, during the irradiation time $t[\mathrm{~s}]$, as the equation.

$$
C_{R n}=\rho / K T .
$$

The sensitivity $K\left(\right.$ track $\left./ \mathrm{m}^{2}\right)$ defined as track density per unit exposure $\left(\mathrm{Bq} \cdot \mathrm{s} / \mathrm{m}^{3}\right)$. Sensitivity traditionally, given in track $/ \mathrm{cm}^{2}$ per Bq d/ $\mathrm{m}^{3}$ (to convert to m must be divided by 8.64 ), where the exposure time $T$ in units of [day].

$K$ can be calculated from equation [14].

$$
K=\frac{1}{4} r\left(2 \cos \theta_{c}-\frac{r}{R_{i}}\right),
$$

where $\theta_{c}$ is the critical angle of LR-115 which equals $40^{\circ}, r$ is the radius of the sealed can $(2 \mathrm{~cm}), R_{i}$ is the range of alpha in the air $(4.09 \mathrm{~cm}$ for the alpha particle energy $5.49 \mathrm{MeV}$ emitted from radon) [15]. Then $K$ equal $(0.5215 \mathrm{~cm})$ multiplying by 0.0864 then its value will be $\left(0.04506 \mathrm{Traks} \cdot \mathrm{cm}^{-2} \cdot \mathrm{day}^{-1} / \mathrm{Bq} \cdot \mathrm{m}^{-3}\right)$.

The radon concentration in the samples calculated using the equation $[16,17]$.

$$
C_{s}=\lambda_{R n} C_{R n} H T / L
$$

where $C_{s}$ is the radon concentration in the cosmetic sample $\left(\mathrm{Bq} / \mathrm{m}^{3}\right), C_{R n}$ is the concentration of air space Radon $\left(\mathrm{Bq} / \mathrm{m}^{3}\right), \lambda_{R n}$ is the constant of decay for Radon $\left(0.1814\right.$ day $\left.^{-1}\right)$, in the can the height of air space is $H(7.5 \mathrm{~cm})$, the time of exposure is $T$ (60 days), and the thickness of the sample is $L(3 \mathrm{~cm})$ in the can.

The sample effective radium content calculated by the equation $[18,19]$.

$$
C_{R a}\left(B q \cdot K g^{-1}\right)=\left(\frac{\rho}{K T_{e}}\right)\left(\frac{H A}{M}\right) .
$$

The sample mass $M$ is in $\mathrm{kg}, A$ in $\mathrm{m}^{2}$ is the cross-section area of the sealed can, the distance from the detector to the top surface of the cosmetic sample is $H$ in meter, $T_{e}$ is time effective exposure in day calculated by the formula:

$$
T_{e}=\left[T-\lambda_{R n}^{-1}\left(1-e^{-\lambda_{R n} T}\right)\right] .
$$

The effective annual radon dose $D_{\text {eff }}(\mathrm{mSv} / \mathrm{y})$ calculated from.

$$
D_{\text {eff }}=C_{R n} O F T_{y} D
$$


where $C_{R n}$ the concentration of radon $\left(\mathrm{Bq} / \mathrm{m}^{3}\right), F$ is an equilibrium factor 0.4 , and $O$ is the occupancy factor its value $0.8, T_{y}\left(8760 \mathrm{~h} \cdot \mathrm{y}^{-1}\right)$ hours is a time of one year, the conversion factor $D$ is $\left(9 \times 10^{-6} \mathrm{mSv} \cdot \mathrm{h}^{-1}\left(\mathrm{~Bq} \cdot \mathrm{m}^{-3}\right)^{-1}\right)[20]$.

\section{Results}

The measurement results of the cosmetics samples are listed in (Table 1).

Table 1

Cosmetic samples, samples weight, track density, radon concentration, radium concentration, radon annual effective dose

\begin{tabular}{|c|c|c|c|c|c|c|}
\hline No. & Samples & Weight, Samp. gm & $P$, Track $/ \mathrm{cm}^{2}$ & $C_{R n}, \mathrm{~Bq} / \mathrm{m}^{3}$ & $C_{R a}, \mathrm{~Bq} / \mathrm{kg}$ & $R n D_{e f f}, \mathrm{mSvy}^{-1}$ \\
\hline 1 & Budy power & 17.89 & 66.66 & 24.69 & 0.143 & 0.622 \\
\hline 2 & Vazalin cream & 24.67 & 26.66 & 9.87 & 0.041 & 0.249 \\
\hline 3 & Lanyan lipstick & 25.2 & 50.90 & 18.85 & 0.077 & 0.475 \\
\hline 4 & Kanza cream & 9.33 & 60.60 & 22.44 & 0.249 & 0.566 \\
\hline 5 & Hina & 15.31 & 64.24 & 23.79 & 0.161 & 0.600 \\
\hline 6 & Soolaf face mask & 24.9 & 75.15 & 27.83 & 0.115 & 0.702 \\
\hline 7 & bulanya eyes shadow & 22.97 & 48.48 & 17.95 & 0.081 & 0.453 \\
\hline 8 & Face mask & 28.36 & 73.93 & 27.38 & 0.100 & 0.690 \\
\hline 9 & eyes shadow sweet rose & 17.07 & 38.78 & 14.36 & 0.087 & 0.362 \\
\hline 10 & Dove cream & 25.1 & 72.72 & 26.93 & 0.111 & 0.679 \\
\hline 11 & fair \& lovely skin cream & 23.67 & 48.48 & 17.95 & 0.078 & 0.453 \\
\hline 12 & blush colors eyes shadow & 18.41 & 81.21 & 30.07 & 0.169 & 0.758 \\
\hline 13 & Nivea cream & 29.85 & 80 & 29.62 & 0.102 & 0.747 \\
\hline 14 & Kokliryu lipstick & 31.34 & 41.21 & 15.26 & 0.050 & 0.385 \\
\hline 15 & Sun blocking & 26.93 & 63.03 & 23.34 & 0.089 & 0.588 \\
\hline 16 & miss five lipstick & 10.2 & 37.57 & 13.91 & 0.141 & 0.351 \\
\hline 17 & Magic lipstick & 16.46 & 73.93 & 27.38 & 0.172 & 0.690 \\
\hline 18 & skincare & 27.87 & 83.63 & 30.97 & 0.115 & 0.781 \\
\hline 19 & Bemat lipstick & 17.37 & 47.27 & 17.50 & 0.104 & 0.441 \\
\hline \multirow[t]{4}{*}{20} & Kuhl & 21.64 & 59.39 & 21.99 & 0.105 & 0.555 \\
\hline & Min & & 26.66 & 9.876 & 0.041 & 0.249 \\
\hline & Max & & 83.63 & 30.97 & 0.249 & 0.781 \\
\hline & Mean & & 59.69 & 22.11 & 0.115 & 0.557 \\
\hline
\end{tabular}

The obtained measured results of 20 cosmetics samples in Table 1, showed that, the samples have different weights because the density of cosmetics differ from one type to another but they have the same volume. The concentrations of radon levels, radium concentration, and annual radon effective dose are having very low measured values, there are no health risks showed the validity for the safe use of cosmetics.

\section{Discussion}

In this study, the determined annual radon effective dose range is $0.249-0.781 \mathrm{mSv} / \mathrm{y}$ with $0.557 \mathrm{mSv} / \mathrm{y}$ the mean value, which is within the range $0.2-10 \mathrm{mSv} / \mathrm{y}$ of (UNSCEAR) [21]. Radon concentrations are in the range $9.87654-30.9764 \mathrm{~Bq} / \mathrm{m}^{3}$, the mean value of $22.11 \mathrm{~Bq} / \mathrm{m}^{3}$, this mean value comparing with other available research results is higher than $0.183 \mathrm{~Bq} / \mathrm{m}^{3}$ of reference [22], and $0.1927 \mathrm{~Bq} / \mathrm{m}^{3}$ from reference [23], much smaller than the reference level limits $100 \mathrm{~Bq} / \mathrm{m}^{3}$ of the World Health Organization (WHO) [24]. Radium contents range between 0.0415-0.249 Bq/Kg, with $0.115 \mathrm{~Bq} / \mathrm{Kg}$ as a mean value. Comparing with the other available 
measurements its very low than the results of 7.9-37.6 Bq/Kg estimated in reference [25]. In the kohl sample, the radium concentration is $0.105 \mathrm{~Bq} / \mathrm{Kg}$ which is lower than $0.866 \mathrm{~Bq} / \mathrm{Kg}$ the results of reference [26]. The obtained results of cosmetics samples showed that, the samples have different concentrations for radon or radium from one type of cosmetic to another, due to its producing composition materials which need to another investigation tools not available here, to know the materials that increase the radiation concentration. This research results importance was in, first is one among a few researches studied radiation concentration in cosmetics, the second its low radiation concentrations measured in these samples so there are no health risks, which mean the safe use of cosmetics.

Fig. 2 represents the radium concentration variation in the samples where show the minimum values in the sample no. 2 Vazalen cream was found, and max values in sample no. 4 Kanza cream. The results show the sample's radiation concentrations are very low and within the low radiation background limit. Cosmetics all the samples have a low contribution to the radon doses.

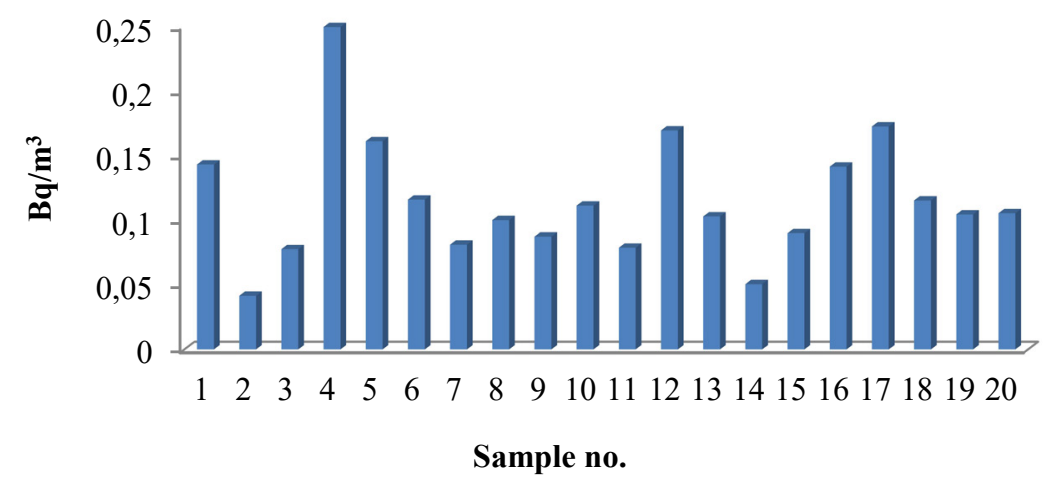

Fig. 2. The radium concentration variation in the samples

\section{Conclusions}

The calculated concentration of radon levels was very lower than the reference level of the World Health Organization (WHO) limits of $100 \mathrm{~Bq} / \mathrm{m}^{3}$, and higher than the available other researcher's values.

The annual radon effective dose is within the internationally acceptable values of the range $0.2-10 \mathrm{mSv} / \mathrm{y}$ of (UNSCEAR), there are no health risks.

The radium concentration range is very lower than the measured value of [25].

The minimum values in the Vazalen cream were found, and max values in Kanza cream.

This work identified law measured concentrations of radionuclide present in the cosmetics, showed the validity for the safe use of cosmetics from the standpoint of the concentrations of radon in them, without posing a radiological threat.

\section{References}

[1] Gagliardi, L., Dorato, S. (2007). General Concepts. Current Legislation on Cosmetics in Different Countries. Analysis of Cosmetic Products, 3-28. doi: https://doi.org/10.1016/b978-044452260-3/50024-3

[2] Patil, A. S., Patil, A. V., Patil, A. H. et. al. (2017). A review on: standerdization of herb in new era of cosmaceuticals: herbal cosmetics. World Journal of Pharmaceutical Research, 6 (12), 303-320.

[3] Fathima, A., Varma, S., Jagannath, P., Akash, M. (2011). General Review on Herbal Cosmetics. International journal of drug formulation and research, 2 (5), 140-165.

[4] Jain, N., Chaudhri, S. (2009). History of cosmetics. Asian Journal of Pharmaceutics, 3 (3), 164. doi: https://doi.org/10.4103/09738398.56292

[5] Dar, A. M. (2011). Cosmetic Chemistry: An Instant Approach. Educreation Publishing, 161. Available at: https://books.google.iq/ books?id=MZ9NDwAAQBAJ

[6] Nouioui, M. A., Mahjoubi, S., Ghorbel, A., Ben Haj Yahia, M., Amira, D., Ghorbel, H., Hedhili, A. (2016). Health Risk Assessment of Heavy Metals in Traditional Cosmetics Sold in Tunisian Local Markets. International Scholarly Research Notices, 2016, 1-12. doi: https://doi.org/10.1155/2016/6296458 
[7] Hardy, A. D., Walton, R. I., Vaishnay, R., Myers, K. A., Power, M. R., Pirrie, D. (2006). Chapter 5 Egyptian eye cosmetics (“Kohls"): Past and present. Physical Techniques in the Study of Art, Archaeology and Cultural Heritage, 173-203. doi: https:// doi.org/10.1016/s1871-1731(06)80006-0

[8] Rentetzi, M. (2008). Trafficking Materials and Gendered Experimental Practices: Radium Research in Early 20th Century Vienna. New York: Columbia University Press.

[9] Thiemann, A. I Fictionalizing Global Climate Change.

[10] Genet, M. (1998). Radium: A Miracle Cure \{exclamation_point\}.

[11] Hallenbeck, W. H. (1993). Quantitative Risk Assessment for Environmental and Occupational Health. CRC Press, 240. doi: https://doi.org/10.1201/9781482264494

[12] Martin, A., Harbison, S. A. (1996). The internal radiation hazard. An Introduction to Radiation Protection, 97-118. doi: https:// doi.org/10.1007/978-1-4899-4543-3_9

[13] Vogiannis, E. G., Nikolopoulos, D. (2015). Radon Sources and Associated Risk in Terms of Exposure and Dose. Frontiers in Public Health, 2. doi: https://doi.org/10.3389/fpubh.2014.00207

[14] Nikezic, D., Yu, K. N., Stajic, J. M. (2014). Computer program for the sensitivity calculation of a CR-39 detector in a diffusion chamber for radon measurements. Review of Scientific Instruments, 85 (2), 022102. doi: https://doi.org/10.1063/1.4865157

[15] Mansy, M., Sharaf, M. A., Eissa, H. M., El-Kamees, S. U., Abo-Elmagd, M. (2006). Theoretical calculation of SSNTD response for radon measurements and optimum diffusion chambers dimensions. Radiation Measurements, 41 (2), $222-228$. doi: https://doi.org/10.1016/j.radmeas.2005.04.004

[16] Somogyi, G., Hafez, A.-F., Hunyadi, I., Tóth-Szilágyi, M. (1986). Measurement of exhalation and diffusion parameters of radon in solids by plastic track detectors. International Journal of Radiation Applications and Instrumentation. Part D. Nuclear Tracks and Radiation Measurements, 12 (1-6), 701-704. doi: https://doi.org/10.1016/1359-0189(86)90683-7

[17] Kheder, M. H., Ahmad, A. M., Azeez, H. N., Slewa, M. Y., Badr, B. A., Sleeman, S. Y. (2019). Radon and uranium concentration in ground water of nineveh plain region in iraq. Journal of Physics: Conference Series, 1234, 012033. doi: https:// doi.org/10.1088/1742-6596/1234/1/012033

[18] Kheder, M. H. (2019). Measurement of Radon Concentration Using SSNTD in Bartella Region. Al-Mustansiriyah Journal of Science, 29 (4), 110. doi: https://doi.org/10.23851/mjs.v29i4.357

[19] Andrade, E., Miró, C., Reis, M., Santos, M., Madruga, M. J. (2017). Assessment of radium activity concentration and radon exhalation rates in iberian peninsula building materials. Radiation Protection Dosimetry, 177 (1-2), 31-35. doi: https://doi.org/ $10.1093 / \mathrm{rpd} / \mathrm{ncx} 128$

[20] Azeez, H. N., Kheder, M. H., Slewa, M. Y., Sleeman, S. Y. (2018). Radon Concentration Measurement in Ainkawa Region Using Solid State Nuclear Track Detector. Iraqi Journal of Science, 59 (1C), 482-488. doi: https://doi.org/10.24996/ijs.2018.59.1c.4

[21] Radiation, United Nations. Scientific Committee on the Effects of Atomic. 2000. 1 Sources and Effects of Ionizing Radiation: Sources. United Nations Publications.

[22] Shakir, A. A., Kadhim, I. H., Almayyalin, A. O. M., Majeed, F. A. (2016). Measurement of Radon Concentration in Some of Cosmetics by Using Nuclear Track Detector (CR-39). International Journal of PharmTech Research, 9 (9), 231-235. Available at: http://www.sphinxsai.com/2016/ph_vol9_no9/1/(231-235)V9N9PT.pdf

[23] Seoud, M. S. (2018). Health Risk Assessment of Radon-222 Concentration in Some Imported Cosmetics by Using Nuclear Track Detector (CR-39). SciFed Journal of Nuclear Science, 2 (2).

[24] WHO Handbook on Indoor Radon: A Public Health Perspective (2009). World Health Organization.

[25] Milena-Pérez, A., Martínez-Martínez, B. R., Álvarez, E., Expósito-Suárez, V. M., Piñero-García, F., Ferro-García, M. A. (2019). Natural radium isotopes present in some cosmetic products: determination of activity concentration and dose estimation. Radiation Protection Dosimetry. doi: https://doi.org/10.1093/rpd/ncz133

[26] Sherif, M. M., Orabi, M., Abdurahem, O. R. (2015). Study of Heavy Elements and Radioactivity Concentrations in Some Eye Cosmetics Commonly Used in Arabic Regions. International Journal of Chemical Engineering and Applications, 6 (1), 66-70. doi: https://doi.org/10.7763/ijcea.2015.v6.453 